\title{
Review \\ Black Elder and Its Constituents: Molecular Mechanisms of Action Associated with Female Reproduction
}

\author{
Adriana Kolesarova ${ }^{1, *}$, Simona Baldovska ${ }^{2}{ }^{\mathbb{D}}$, Ladislav Kohut ${ }^{1}$ and Alexander V. Sirotkin ${ }^{3}$ \\ 1 Institute of Applied Biology, Faculty of Biotechnology and Food Sciences, \\ Slovak University of Agriculture in Nitra, 94976 Nitra, Slovakia; ladislav.kohut@uniag.sk \\ 2 AgroBioTech Research Centre, Slovak University of Agriculture in Nitra, 94976 Nitra, Slovakia; \\ simona.baldovska@uniag.sk \\ 3 Department of Zoology and Anthropology, Faculty of Natural Sciences, \\ Constantine the Philosopher University in Nitra, 94901 Nitra, Slovakia; asirotkin@ukf.sk \\ * Correspondence: adriana.kolesarova@uniag.sk; Tel.: +421-37-641-4119
}

Citation: Kolesarova, A.; Baldovska, S.; Kohut, L.; Sirotkin, A.V. Black Elder and Its Constituents: Molecular Mechanisms of Action Associated with Female Reproduction.

Pharmaceuticals 2022, 15, 239.

https://doi.org/10.3390/ph15020239

Academic Editor: Monica

Notarbartolo

Received: 18 January 2022

Accepted: 15 February 2022

Published: 17 February 2022

Publisher's Note: MDPI stays neutral with regard to jurisdictional claims in published maps and institutional affiliations.

Copyright: (C) 2022 by the authors. Licensee MDPI, Basel, Switzerland. This article is an open access article distributed under the terms and conditions of the Creative Commons Attribution (CC BY) license (https:// creativecommons.org/licenses/by/ $4.0 /)$.

\begin{abstract}
The present review summarizes the current knowledge concerning provenance, properties, physiological and therapeutic actions of elderberry and the bioactive molecules present in the plant, with emphasis on their action on female reproduction. Elderberry or black elder (Sambucus nigra L.) attracts attention due to its easy cultivation and high availability of bioactive compounds. Most of the available data concerning black elder's therapeutic action are focused on its effects such as activation of immune processes and anti-inflammatory processes (cytokine production, etc.) and regulation of hormones and their receptors in cancer cells. The effects of elderberry on reproduction have been poorly investigated so far. Nevertheless, conducted studies so far demonstrate the stimulatory influence of black elder extract and its constituents, such as rutin, anthocyanins and agglutinins, on the viability and steroidogenesis of healthy ovarian cells as well as their ability to promote apoptosis and reduce the viability and proliferation of ovarian cancer cells. Furthermore, the action of black elder extract and its constituent biomolecules, such as anthocyanins and lectins, on embryogenesis and the embryonal estradiol-estradiol receptor system have also been reported. The available information, despite limitations, suggest the applicability of black elder constituents for improvement of reproductive processes in animal biotechnology, animal production and assisted reproduction, as well as for prevention and treatment of reproductive disorders (including cancer) in veterinary and human medicine.
\end{abstract}

Keywords: elderberry; rutin; anthocyanins; agglutinins; steroidogenesis; proliferation; apoptosis; reproductive biology; reproductive disorders; cancer

\section{Introduction}

The search for new regulators of reproduction is important for the solution of various problems of modern society. Intensive animal production is associated with growing incidences of farm animal infertility [1]. The occurrence of reproductive disorders is currently growing in all mammalian species [2]. The inability to have children affects $10 \%$ to $20 \%$ of all couples in the modern world, which promotes the development of reproductive medicine and assisted reproduction. Subfertility affects many more people [3-5]. Moreover, gynecological cancers are the key cause of mortality in women [6]. Biotechnology in animal production (from artificial insemination to generation of transgenic organisms) is focused on reproductive processes; therefore, its development requires a search for new regulators and medicines affecting these processes [7].

The majority of reproductive dysfunctions have similar causes and mechanisms-the ability of various adverse environmental factors to induce oxidative stress-including the accumulation of reactive oxygen species, which are deleterious to DNA and proteins, 
ovarian folliculogenesis and embryogenesis. Oxidative stress can be prevented by antioxidants [4]. The most natural, accessible and inexpensive sources of antioxidants, which can affect reproductive processes and prevent numerous reproductive disorders, are plants [6,8]. Additionally, because of implications on health, there is a growing interest in the use of plant-based antioxidants in the food industry. In this regard, replacing synthetic additives with natural bioactive compounds extracted from plants has been an important strategy for food manufacturers [9-11].

One of the promising and widely accessible sources of antioxidants and other biologically active substances affecting reproductive and non-reproductive processes and health could be the black elderberry (Sambucus nigra L.). Due to its health-promoting and sensory properties, elderberry is used primarily in the food and pharmaceutical industries [12]. The popularity of this plant among food and pharma producers is growing due to its simple cultivation, high availability and high number and quantity of bioactive compounds with physiological and therapeutic properties [10,13].

\section{Provenance and Properties}

Black elderberry belongs to the Adoxaceae family, and its common names are elder, elderberry, black elder, European elder, European elderberry, and European black elderberry [14]. Sambucus nigra is a small tree or shrub, 1-8 $\mathrm{m}$ tall with a strong odor. The bark is brownish, with longitudinal fractures and deep grooves. The leaves are opposite, imparipinnate, with 5-7 elliptic-lanceolate, dentate leaflets. The inflorescence is an umbel with many milky-white flowers. The fruit is a shiny black-purple color, with a subspherical drupe. The plant is found in woods, clearings and hedges from sea level to mountainous elevations [15].

Black elderberry is an extremely accessible and abundant plant native to the Northern hemisphere. Their seeds are spread rapidly by birds and other animals to colonize forest edges and disturbed areas and are nowadays diffused in various habitats including subtropical regions of Asia, North Africa and North America [12,16,17]. Since the beginning of 1980s, black elderberry has been planted and commercialized in some countries in Europe, the USA, Canada, New Zealand and Chile [16]. In Europe, elderberries have been intensively used for centuries both in the food industry to produce pies, jellies, jams, ice creams, yogurts and different alcoholic beverages [17], and in folk medicines for treatment of various diseases and ailments due to their antioxidant, anticarcinogenic, immune-stimulating, antiallergic, antiviral and antibacterial properties [18]. These aspects of elderberry have recently received significant attention, especially for antioxidant capacity, as functional compounds in food applications such as natural conservatives or food supplements [19].

All parts of this plant (flower, bark, leaf and fruits) are rich sources of dietary phytochemicals, such as carbohydrates, lipids, terpenoids, flavonoids, phenolic acids, alkaloids, etc. $[16,20]$. The content of the essential fatty acids, such as linoleic and $\alpha$-linolenic acids, is very high (approximately 39\% each), and the polyunsaturated fatty acids represent $78 \%$ of the total fatty acids. The most prominent compounds present in black elderberry fruits are polyphenols, e.g., anthocyanins, with high antioxidant capacity. The major elderberry anthocyanins are cyanidin-3-glucoside and cyanidin-3-sambubioside, which are found in elderberry juice and polar extracts [21-23]. In addition, elderberries are a rich source of flavanols, phenolic acids and procyanidins. Elderflowers are particularly rich in flavonoids (up to 3\%), such as kaempferol, astragalin, quercetin, quercetin-3-O-glucoside, rutin, isoquercitrin and hyperoside, as well as phenolic acids, gallic acid and gentisic acid [9,23,24]. The most abundant polyphenol in elderflower is the flavonoid rutin [25]. Our screening of elderflower extract confirmed that this plant represents a rich source of polyphenols, and the most prominent compound present in elderberry extracts from flowers and berries was the flavonoid rutin [26]. Additionally, other types of polyphenols like flavonol glycosides and flavonol esters are present in elderberries [27]. Other known biologically active substances in elderberry include lectins, especially agglutinins, cyanogenic glycosides, essential oils, fatty acids, organic acids, carbohydrates, vitamins and minerals [12,28-33]. 
Every $100 \mathrm{~g}$ serving of fresh berries contains vitamin B2 $(65 \mathrm{mg})$, vitamin B6 $(0.25 \mathrm{mg})$, vitamin C (18-26 mg), folic acid (17 mg), biotin (1.8 mg), $\beta$-carotene $(0.36 \mathrm{mg})$, pantothenic acid $(0.18 \mathrm{mg})$, nicotinamide $(1.48 \mathrm{mg})$, potassium (288-305 mg), phosphor (49-57 mg), pectin $(0.16 \%)$ and glucose and fructose $(7.5 \%)$ [34].

The characteristic aroma of elderberries is a result of (E)- $\beta$-damascenone, dihydroedulan, ethyl-9-decenoate, 2-phenyl ethanol, phenylacetaldehyde and nonanal. Alcohols, esters and aldehydes are frequently identified volatile groups in elderberries. Other major secondary metabolites comprise approximately $1 \%$ triterpenes (as $\alpha$ - and $\beta$-amyrin, ursolic acid and oleanolic acid) and about $1 \%$ sterols ( $\beta$-sitosterol, campesterol and stigmasterol). In addition, pectins, tannins and phenolic acids are found in the flowers [35,36]. Elderflowers have a strong, flowery, pleasant odor mainly due to the presence of $0.03-0.14 \%$ of essential oils. In addition, the aroma composition of elderflowers includes aldehydes, ketones, alcohols, esters, oxides, terpenes and free fatty acids [37]. The bark, leaves, seeds and raw or unripe fruits contain the cyanogenic glycoside sambunigrin, which is potentially toxic because it can release cyanide [23,38,39].

Therefore, various parts of the elderberry plant demonstrate the presence of high amounts of biologically active molecules with a wide spectrum of effects-from antioxidative and phytoestrogenic polyphenols to toxic aldehydes and glycosides. The presence of these molecules could explain the physiological and therapeutic effects of this plant, as well as the variability in its action on different targets listed below.

\section{Physiological and Therapeutic Actions of Elderberry and Its Constituents}

Elderberry is widely used in folk medicine through its pharmacological properties [40]. Currently, it presents as one of the most used medicinal plants worldwide [41]. In folk medicine, elderberry is used in the treatment of many diseases and ailments thanks to its antioxidant, anticarcinogenic, immune stimulating, antiallergic, antiviral, antibacterial [12,18,28], antidepressant and hypoglycemic properties, as well as the ability to reduce body fat and blood lipid concentrations [12]. Elderberry flowers can be used both for prevention and therapy of a wide array of diseases due to immunomodulatory [42,43], antiinflammatory [44-46], antioxidant [28,47-50], antimicrobial [12,51,52] and antiviral $[41,53,54]$ activities. In vitro experiments demonstrated the ability of elderberry extract or its constituents to suppress proliferation and viability of various cancer cell lines $[25,33,55-58]$ and to prevent angiogenesis in tumor $[55,59]$. On the other hand, in some cases (estrogenic breast cancer cells and osteosarcoma cells), the biomolecule rutin found in the black elderberry did not affect cancer cell viability [60]. However, it could improve the acetic acid-induced colitis [28]. There are some reports on the neuromodulatory, particularly anticonvulsant [61] and analgesic [28,62], effects of elderberry extracts. In rats, this extract induced central depression [28], but experiments on mice showed its antidepressant activities [63].

Elderflowers have been used in traditional medicines for the management of inflammation, skin disorders such as diuretic, colds, fevers and other respiratory disturbances $[28,64,65]$. For example, it has the potential to ameliorate skin photoaging and inflammation [66]. Elderberry extract inhibited the infectious bronchitis virus at an early point during replication [67-69]. Consumption of elderberry extract has also been suggested for people with diabetic osteoporosis for improving lipid profile and reducing atherogenic risk and hyperglycemia [70]. In vitro studies suggested that elderflower extracts stimulate insulindependent glucose uptake [71-73]. It can improve functions of the cardiovascular system, improve exercise performance and mitigate the risk of cardiovascular diseases [62]. Elderberry anthocyanins can be efficient against atherosclerosis and Helicobacter pylori, a noxious pathogen responsible for various gastrointestinal disorders including duodenal ulcer and gastric cancer [55]. There is evidence for the applicability of black elderberry for the treatment of obesity $[74,75]$. Recently, elderberry has received significant attention from food producers due to its applicability as a natural food conservator [19]. For better visualization of the physiological and therapeutic actions of elderberry, we summarize in vitro and in vivo studies, elderberry preparation, experimental models and effects observed in Table 1. 
Table 1. Physiological and therapeutic actions of elderberry.

\begin{tabular}{|c|c|c|c|c|}
\hline Therapeutic Actions & Elderberry Preparation & Experimental Model & Results & Ref. \\
\hline Antimicrobial activity & Water elderberry fruit extract & $\begin{array}{c}\text { Mycoplasma mycoides subspecies capri strain GM12, } \\
\text { Escherichia coli strain DH5 } \alpha \text { and Bacillus subtilis } \\
\text { strain ATCC } 6051\end{array}$ & In vitro growth inhibition of bacterial pathogens & [51] \\
\hline \multirow[b]{2}{*}{ Antiviral activity } & $\begin{array}{l}\text { Ethanol elderberry fruit extract } \\
\text { Concentrated elderberry fruit juice }\end{array}$ & Madin-Darby canine kidney cells (MDCK) & Inhibition of Human Influenza A (H1N1) virus & {$[53,54,68]$} \\
\hline & Concentrated elderberry fruit juice & $\begin{array}{l}\text { Female BALB/c mice infected with influenza } \\
\text { A virus }\end{array}$ & $\begin{array}{l}\text { Suppression of the viral replication in the bronchoalveolar lavage } \\
\text { fluids (BALFs); increase of the human influenza A virus } \\
\text { (IFV)-specific neutralizing antibody in the serum; increase of } \\
\text { secretory IgA in BALFs and feces }\end{array}$ & [54] \\
\hline \multirow[b]{3}{*}{ Anti-inflammatory activity } & $\begin{array}{l}\text { Ethanol elderberry fruit } \\
\text { Elderflower extract }\end{array}$ & $\begin{array}{l}\text { Lipopolysaccharide (LPS)-activated cells RAW } \\
264.7 \text { and dendritic cells D2SC/I }\end{array}$ & $\begin{array}{c}\text { Strong complement fixating activity and inhibitory effect on NO } \\
\text { production }\end{array}$ & [44] \\
\hline & $\begin{array}{l}\text { Gastrointestinal digested water } \\
\text { elderberry fruit extract }\end{array}$ & $\begin{array}{c}\text { Co-cultured human intestinal epithelial cells } \\
\text { Caco-2 and lipopolysaccharide (LPS)-activated } \\
\text { cells RAW } 264.7\end{array}$ & $\begin{array}{l}\text { Downregulation the expression of major genes of inflammatory } \\
\text { pathway IL- } 1 \beta, \text { IL- } 6 \text {, TNF- } \alpha \text { and COX-2 }\end{array}$ & [46] \\
\hline & Ethanol elderberry fruit extract & Human skin keratinocytes HaCaTs & $\begin{array}{l}\text { Protective effect against UVB-induced skin photoaging and } \\
\text { inflammation; suppression of UVB-induced matrix } \\
\text { metalloproteinase-1 (MMP-1) expression and inflammatory } \\
\text { cytokine secretion; inhibition of mitogen-activated protein } \\
\text { kinases/activator protein } 1 \text { (MAPK/AP-1) and nuclear factor- } \mathrm{kB} \\
\text { (NF-kB) signaling pathways }\end{array}$ & [66] \\
\hline \multirow{3}{*}{ Immuno-modulatory activity } & Elderberry fruit juice & Alveolar carcinoma cells A549 & $\begin{array}{l}\text { Stimulation of human inflammatory cytokines IL-6, IL-8 and } \\
\text { TNF production }\end{array}$ & [68] \\
\hline & Water elderberry fruit extract & Murine-derived dendritic cells & $\begin{array}{l}\text { Stimulation of } L \text {. acidophilus-induced IL- } 12 \text { and IFN- } \beta \text { production } \\
\text { Stimulation of the inflammatory cytokines IL- } 1 \beta \text {, IL- } 6 \text {, IL- } 8 \text { and }\end{array}$ & [42] \\
\hline & Elderberry extract syrup Sambucol & Normal human monocytes & $\begin{array}{l}\mathrm{TNF} \alpha \text { production; causes a shift in the immune response to } \\
\text { inflammation-associated Th1 responses }\end{array}$ & [43] \\
\hline \multirow{2}{*}{ Antioxidant activity } & $\begin{array}{l}\text { Water elderberry fruit extract } \\
\text { Ethanol elderberry fruit extract }\end{array}$ & $\begin{array}{l}\text { Human intestinal epithelial cells Caco-2 and } \\
\text { human skin keratinocytes HaCaTs }\end{array}$ & $\begin{array}{l}\text { Reduction in the intracellular reactive oxygen species } \\
\text { (ROS) production }\end{array}$ & {$[46,66]$} \\
\hline & Water elderberry fruit extract & Weissberger's biogenic oxidative system & $\begin{array}{l}\text { Inhibition of oxidative degradation of hyaluronan (HA); ability to } \\
\text { scavenge free radicals }\end{array}$ & [50] \\
\hline
\end{tabular}


Table 1. Cont.

\begin{tabular}{|c|c|c|c|c|}
\hline Therapeutic Actions & Elderberry Preparation & Experimental Model & Results & Ref. \\
\hline \multirow{3}{*}{ Anticancer activity } & Ethanol elderflower extract & Breast carcinoma cells MCF7 & $\begin{array}{l}\text { Protective effect against breast cancer by reduction of cell } \\
\text { proliferation; inhibition of estrogen secretion, downregulation of } \\
\text { ER } \alpha \text { and upregulation of PR }\end{array}$ & [57] \\
\hline & Butanolic elderflower extract & $\begin{array}{l}\text { Bladder carcinoma cells T24 and human } \\
\text { fibroblast cells MRC- } 5\end{array}$ & Selective cytotoxic activity in cancer cells & [58] \\
\hline & Sambucus nigra agglutinin & $\begin{array}{l}\text { Epithelial ovarian adenocarcinoma cells OAW-42, } \\
\text { p53 null OC cells SKOV3, normal epithelial } \\
\text { ovarian cell line IOSE-364, mouse fibroblast cells } \\
\text { NIH3T3 and lung carcinoma cells A549 }\end{array}$ & $\begin{array}{l}\text { Protective effect against ovarian cancer by induction of apoptosis } \\
\text { in cancer cells and cell cycle arrest before G2/M phase; inhibition } \\
\text { of cancer progression; mitochondrial dysfunction through } \\
\text { increase in ROS generation and cytochrome-c release; shift of } \\
\text { cellular respiration toward oxidative phosphorylation }\end{array}$ & [33] \\
\hline Antidepressant activity & Methanol elderberry fruit extract & Male Swiss albino mice & $\begin{array}{c}\text { Antidepressant potential in forced swimming test (FST) and tail } \\
\text { suspension tests (TST) }\end{array}$ & [63] \\
\hline \multirow{4}{*}{ Antidiabetic activity } & Aqueous elderflower extract & Mice abdominal muscles & $\begin{array}{c}\text { Increase in muscle glucose uptake, glucose oxidation } \\
\text { and glycogenesis }\end{array}$ & [73] \\
\hline & Aqueous elderflower extract & Rat pancreatic beta-cells BRIN-BD11 & Stimulation of insulin secretion & [73] \\
\hline & $\begin{array}{l}\text { Methanol polyphenolic elderberry } \\
\text { fruit extract }\end{array}$ & $\begin{array}{l}\text { Wistar white male rats, streptozotocin } \\
\text { (STZ)-induced hyperglycemic rats }\end{array}$ & $\begin{array}{c}\text { Reduction in the body fat in diabetic rats; decrease in the lipid } \\
\text { peroxidation level in serum }\end{array}$ & [70] \\
\hline & Methanol elderflower extract & Primary porcine myotube cultures & Modulation of glucose; increase in glucose uptake & [71] \\
\hline Antiosteoporosis activity & $\begin{array}{l}\text { Methanol polyphenolic elderberry } \\
\text { fruit extract }\end{array}$ & $\begin{array}{l}\text { Wistar white male rats, streptozotocin } \\
\text { (STZ)-induced hyperglycemic rats }\end{array}$ & Improvement of the bone mineral density and osteoporosis status & [70] \\
\hline \multirow[t]{2}{*}{ Anti-obesogenic activity } & Methanol elderflower extract & Mouse embryonic fibroblast cells 3T3-L1 & $\begin{array}{l}\text { Activation of the peroxisome proliferator-activated receptor } \\
\text { (PPAR) } \gamma ; \text { stimulation of insulin-dependent glucose uptake }\end{array}$ & [72] \\
\hline & Methanol elderflower extract & Primary porcine myotube cultures & $\begin{array}{l}\text { Modulation of lipid metabolism; reduction of } \\
\text { fat accumulation }\end{array}$ & [71] \\
\hline \multirow{2}{*}{ Aromatase activity } & $\begin{array}{l}\text { Ethanol elderberry fruit } \\
\text { Ethanol elderflower extract }\end{array}$ & Human ovarian granulosa cells HGL5 & $\begin{array}{l}\text { Stimulatory effect on ovarian steroidogenesis; upregulation of } \\
\text { steroid hormone secretion }\end{array}$ & [26] \\
\hline & Ethanol elderflower extract & Chorion carcinoma cell lines JEG-3 and BeWo & Inhibition of estradiol secretion and ER $\alpha$ upregulation & [57] \\
\hline
\end{tabular}


No substantial adverse side effects of black elderberry have been reported so far [23]. Moreover, there are a growing number of reports concerning the physiological and curative actions of elderberry. Nevertheless, the majority of these effects were shown only on limited numbers of animals or in vitro experiments, whilst clinical trials are rare. Sometimes the effect of elderberry was influenced by the kind of its extract (aqueous or ethanol), indicating the influence of solvent itself or that different solvents are extracting different plant molecules [28]. The hierarchical interrelationships (primary and secondary effects) are possible; for example, the anti-obesity and antidiabetic effects of elderberry could be explained by its stimulatory action on glucose uptake and fat metabolism.

\section{Mechanisms of Action of Elderberry and Its Constituents}

\subsection{Constituents Responsible for Particular Effects of Elderberry}

It is widely accepted that elderberries' curative capacity is due to the presence of high amounts of polyphenolic compounds, primarily flavonols, phenolic acids and anthocyanins. The presence of polyphenols, which assure the defense of plants against pathogenic microorganisms, can also explain the ability of black elderberry to suppress the activity of viruses $[41,53,54]$ and bacteria in the body [12,51,52] and in food items [19].

Plant polyphenols are known free radical scavengers and are able to protect the human body against oxidative stress and peroxidative processes [62,76-78]. The strong antioxidant capacity of elderberries is probably related to the most abundant and biologically active flavonols rutin and quercetin, as well as to gallic acids [79]. Rutin (the most abundant polyphenol in elderflower) was found to inhibit the viability of human neuroblastoma [25], leukemic [56] and breast cancer [57] cells. Therefore, the anticancer activity of black elderberry can be due to the presence of rutin. On the other hand, the ability of elderberries' anthocyanins to suppress malignant transformation of endothelioma cells has also been demonstrated $[55,80]$. These reports suggest the anticancer effects of several elderberry polyphenols, which could act as synergists.

There is evidence that the positive action of elderberry on vascular health is due to the presence of anthocyanins, especially cyanidin-3-O-glucoside [59,62]. Moreover, elderberry agglutinins can selectively bind to apoptotic cells, and can be involved in the execution of mitochondrial apoptosis in various cell types [81]. Finally, elderberry agglutinin can block vascular endothelial growth factor (VEGF)-induced angiogenesis [82], which plays an important role in tumor growth. These observations indicate that the pro-apoptotic action of elderberry could be due to the presence of agglutinins. The elderberry constituents responsible for other effects of this plant remain to be identified yet.

It may, however, be noted that search for an active compound of any plant, including elderberry, is difficult because the tested commercial and non-commercial dietary supplements usually contain multiple ingredients. In addition, substantial differences are often found between labelled and actual ingredients or their amounts [23]. Furthermore, the hypothesis concerning active components of elderberry, which are responsible for a particular effect, is based usually on a similarity of the whole plant extract's effect and its putative constituent(s). To our knowledge, the effect of the elderberry extract and the effect of its constituents have not been compared in a single experiment yet.

\subsection{Mediators of Effects of Elderberry and Its Constituents}

As mentioned above, several curative effects of elderberry could be explained by high contents of antioxidants, which can either directly eliminate free oxygen species or promote antioxidative enzymes within the cells [62,76-78]. Mitigation of oxidative stress and protection of genomic DNA integrity are probably the main mechanisms of elderberry's inhibitory action on carcinogenesis, blood vessels, brain functions, inflammatory and gut microbiota [55,80], skin aging and inflammation [66].

Furthermore, the antioxidative and anticancer effects of elderberry anthocyanins are associated with the downregulation of promoters and markers of inflammation, such as monocyte chemoattractant protein-1 (MCP-1), transcription factor nuclear factor kappa 
$B(\mathrm{NF}-\mathrm{kB})$ and interleukin 8 (IL-8). Some similar signaling substances were changed during curative elderberry action on skin photoaging and inflammation. This effect was associated with a decrease in matrix metalloproteinase-1 (MMP-1) expression, secretion of inflammatory cytokines, mitogen-activated protein kinases/activator protein 1 (MAPK/AP1) and NF-KB signaling pathways and skin inflammation. In addition, elderberry extract improved nuclear factor E2-related factor 2/heme oxygenase-1 (Nrf2/HO-1) signaling to increase oxidative defense capacity, enhanced transforming growth factor beta (TGF- $\beta$ ) signaling activation to promote procollagen type I synthesis and blocked extracellular matrix degradation [66].

The protective effect of elderberry flavonoids and pectins against the influenza virus is probably mediated by stimulating the immune system of the host through enhancing the production of inflammatory cytokines such as interleukins IL-6, IL-8 and tumor necrosis factor (TNF) $[54,68,83]$ and the subsequent stimulation of macrophages [84]. Therefore, elderberry antioxidants could protect the target tissues via reduction of oxidative stress and the downregulation of regulators of inflammatory processes.

In addition, black elderberry anthocyanins can improve vascular health by promoting the production of nitric oxide, which in turn promotes vascular permeability and vasodilation and reduces blood pressure [62]. On the other hand, tumor anthocyanin cyanidin-3-glucoside can suppress angiogenesis via the downregulation of production of VEGF and STAT-3, a post-receptor mediator of VEGF action on vascular development [59]. Elderberry lectins can downregulate angiogenesis via a blockade of VEGF receptors [82].

Finally, elderberry can influence some physiological processes via changes in steroid hormones and their receptors. Elderflower extracts promoted estradiol release, downregulated estrogen receptor alpha and upregulated progesterone receptor expression in cultured breast cancer cells, which are involved in the control of cell proliferation [57]. The endocrine effects of elderflower could be due to phytoestrogen activity of several elderberry polyphenols, i.e., their ability to bind steroid hormone receptors and to affect the release of steroid hormones and hormone-dependent events [85].

Taken together, the available data suggest that the non-reproductive effects of black elderberry are mediated by changes in oxidative, inflammatory, and regenerative processes, as well as angiogenesis, steroid hormones and their receptors. The functional interrelationships between these processes are possible. At least, the influence of oxidative stress and antioxidants on inflammatory processes, which in turn trigger cancerogenesis/carcinogenesis, has been suggested [86]. Furthermore, the adverse effects of oxidative stress on steroidogenesis and nitric oxide have been documented $[87,88]$. Nevertheless, the functional interrelationships between particular signaling pathways mediating elderberry actions require further elucidation. Furthermore, various elderberry constituents could affect different targets via several mediators - this hypothesis, however, requires validation by further studies.

\section{Effects of Elderberry and Its Constituents on Female Reproductive Processes}

\subsection{Effect of Elderberry and Its Constituents on Ovarian Cell Viability, Apoptosis and Proliferation}

Our recent in vitro study demonstrated the promising stimulatory effect of elder-berry extracts on the viability of human ovarian granulosa cells [26]. This in vitro study indicated an increase in the number of viable ovarian cells after the addition of the ex-tracts from different parts of the elderberry plant (flowers and berries).

The role of a particular elderberry molecule responsible for its effect could be detected by comparison of the effects of the whole elderberry extract and its particular constituents. The most known biologically active constituents of elderberry are rutin, anthocyanins and agglutinins. The most abundant polyphenol in elderflower and elderberry is the flavonoid rutin $[25,26]$. The comparison of the effects of elderberry extract and rutin showed the similar effects for the extracts and its major component. In experiments of Sirotkin et al. $[8,89]$, the addition of rutin was found to increase the viability of cultured porcine ovarian granulosa cells, although this effect was not associated with changes in 
the accumulation of markers of proliferation (accumulation of PCNA) and cytoplasmic apoptosis (Bax). In vivo experiments, like in vitro ones, demonstrated the stimulatory action of rutin on rat ovarian cell health and ovarian folliculogenesis [90,91].

In contrast to healthy ovarian cells, in the case of cultured cancer cells, native and hydrolyzed rutin exerted in vitro inhibitory activity against human ovarian adenocarcinomas by suppression of the viability and proliferation of OVCAR-3 ovarian carcinoma cells $[92,93]$. Additionally, the viability and proliferation of ovarian cancer cells were reduced by other elderberry constituents such as anthocyanins [94], glycosylated cyanidin derivatives [95] and delphinidin [96]. Another elderberry constituent, agglutinins, was reported to reduce viability and mitochondrial activity and also induce apoptosis of cultured ovarian cancer cells [33].

The present observations suggest the stimulatory influence of black elderberry substances on the viability of healthy ovarian cells and the ability of elderberry to promote apoptosis and reduce the viability of cultured ovarian cancer cells. These phenomena suggest that this plant can be principally useful for stimulation of healthy ovarian cells and suppression of cancer ovarian cell functions. The comparison of the action of elderberry and its constituents indicates that its action on ovarian cell viability and proliferation can be due to the presence of rutin, anthocyanins and/or agglutinins.

\subsection{Effect of Elderberry and Its Constituents on Ovarian Cell Steroidogenesis}

Our recent study demonstrated the influence of both elderberry extracts from dark purple elderberry fruits, as well as from elderflowers on steroid hormone release by cultured human granulosa cells. The release of both progesterone and 17ß-estradiol by the cells was increased after supplementation by either elderflower extract or extract from the berries of the shrub. The results of this study demonstrated the benefits of elderberry extracts prepared from different parts of plant (flowers and fruits) in the upregulation of biosynthesis of ovarian steroid hormones in vitro [26].

According to the above-mentioned hypothesis, the black elder constituents responsible for the elderberry's effects on ovarian steroidogenesis are to be suggested on the basis of the similarity of effects. Such similarity in elderberry and rutin has been reported. In vivo and in vitro studies on rats demonstrated the ability of rutin to promote the plasma luteinizing hormone (LH) level, expression of ovarian follicle-stimulating hormone (FSH) receptors, steroidogenic enzymes, ovarian folliculogenesis and fecundity [90,91]. In in vitro experiments with cultured porcine granulosa cells, the addition of rutin was able to promote $17 \beta$-estradiol and testosterone, but not progesterone release $[8,89,97]$. It is not to be excluded that the increase in granulosa cell viability under the influence of elderberry extract could be due to the upregulation of estradiol, a known promoter of ovarian cell viability and ovarian folliculogenesis [98].

The current literature does not portray evidence concerning anthocyanins' action on ovarian steroidogenesis, although the phytoestrogenic effects of anthocyanins, especially of cyanidin and delphinidin, have been reported $[99,100]$. The high dietary consumption of anthocyanins by humans was associated with a lower level of plasma dehydroepiandrosterone, but not of progesterone, androgens and estrogens [101]. The stimulatory action of anthocyanin cyanidin-3-O-glucoside on FSH, LH receptors and testosterone production by mice testis has been shown [102], but similar experiments on females have not been reported.

Again, the current literature does not demonstrate the changes in ovarian steroidogenesis under influence of agglutinins. Therefore, there is no evidence so far that elderberry action on ovarian steroid hormones could be due to anthocyanins or agglutinins. On the other hand, the high similarity in stimulatory action of elderberry extract and rutin on healthy granulosa cell viability and steroidogenesis suggests that plant action on ovarian cells can be due to the presence of the most abundant plant flavonol rutin. Furthermore, the steroid-promoting effect of elderberry indicates the potential applicability of this plant 
and its constituent rutin for the promotion of steroid-dependent non-reproductive and reproductive events including ovarian folliculogenesis and fecundity.

\subsection{Effect of Elderberry and Its Constituents on Embryo}

Schröder et al. [57] did not find any effect of elderflower extract on the proliferation of human embryonal trophoblast cancer cells. This observation is in line with the absence of action of the main elderberry constituent rutin on the embryogenesis of Xenopus laevis [103] or on the viability of cultured human lung embryonic fibroblasts and human umbilical vein endothelial cells [104]. Therefore, the influence of elderflower or its constituent rutin on embryonal cells has not been detected yet.

Other black elder constituents, such as anthocyanins [105], and here especially cyanidin (but not kuromanin) [106], were able to improve the quality and developmental capacity of porcine embryos indicating the stimulatory action of elderberry anthocyanins on embryogenesis. A similar ability to increase the viability of chicken embryonal fibroblast cells was reported for another anthocyanin, the nightshade anthocyanin [107].

In contrast to elderberry anthocyanin, elderberry lectins blocked receptors of vascular endothelial growth factor (VEGF) in embryonal tissue, which is responsible for embryonal angiogenesis (endothelial cell proliferation and motility) [82]. These data indicate the stimulatory action of black elderberry anthocyanin and the adverse effect of its lectins on embryogenesis.

Schröder et al. [57] also studied the effect of elderflower extracts on the production of estradiol and estrogen receptors alpha (ER- $\alpha$ ) using trophoblast tumor cell lines JEG-3 and BeWo. Elderflower extracts inhibited estradiol production in JEG-3 cells and prompted in BeWo cells. Furthermore, it upregulated the accumulation of estradiol receptors in JEG-3 cell lines. These observations demonstrate that black elderberry extract can affect embryonal trophoblast and its estradiol-estrogen receptor system, which could be responsible for embryo development and maintenance of gravidity. Furthermore, it indicates the black elderberry's influence on trophoblast cancerogenesis.

Therefore, the available publications indicate both stimulatory and inhibitory actions of elderberry extract and its constituents rutin, anthocyanins and lectins on regulators of embryogenesis, embryonal cancerogenesis and steroidogenesis. The ability of steroid hormones to promote both embryo development [108] and malignant transformation [109] is well-known. Therefore, the influence of elderberry molecules' action on embryo and cancerogenesis through the estrogen/estrogen receptor system could be proposed. Nevertheless, understanding such interrelationships, causes in variability in elderberry molecules on various embryonal targets, their biological significance and practical applicability requires further profound studies.

\section{Extracellular Mechanisms of Action of Elderberry and Its Constituents on Female Reproductive Processes}

Although numerous signaling pathways are involved in elderberry action on nonreproductive processes, research enabled the identification of only some pathways mediating the effect of black elderberry on reproduction, and less studies have been performed to detect mediators of this plant's action on female reproductive processes.

The direct action of the elderberry extract on reproductive organs and the ability to affect cultured ovarian [26] and embryonal trophoblast [57] cells was demonstrated. Moreover, the elderberry constituents, such as rutin [8,89,92,93], anthocyanins [94-96], and agglutinins [33] directly influence the viability, proliferation and apoptosis of ovarian cells.

The ability of elderberry constituents rutin [90,91] and anthocyanins [102] on LH and FSH release indicate that they could regulate reproductive functions through the upregulation of pituitary gonadotropins. The ability of rutin to affect ovarian gonadotropin receptors $[90,91]$ indicates that these receptors could be the next mediators of elderberry action on the ovary. 
Elderberry extract affected steroid hormones release by ovarian granulosa cells [26] and embryonal trophoblast cells [57]. The influence of elderberry molecule rutin [90,91], but not of anthocyanins and agglutinins, on ovarian steroidogenesis has also been reported. These observations suggest that steroid hormones could be one of the mediators of the black elderberry and its molecule rutin on ovarian functions, and so can promote ovarian cell viability through the stimulation of steroidogenesis [98]. Finally, the influence of elderberry extract on embryonal cancer cell estrogen/estrogen receptor systems [57], as well as the importance of this system in control of embryogenesis [108] and cancerogenesis [109], indicate that elderberry can affect embryos via estrogens and its receptors. Nevertheless, such hypotheses require direct experimental confirmation.

\section{Intracellular Mechanisms of Action of Elderberry and Its Constituents on Female Reproductive Processes}

The current literature does not contain evidence concerning the intracellular mechanisms of the whole elderberry extract action on ovarian cells; however, there are some reports concerning the key elderberry constituents (rutin, anthocyanins, agglutinins) on cultured ovarian cells and cancer cells, which could help to understand the mediators of elderberry actions on either healthy or malignant cells.

Treatment of mice with rutin boosted ovarian follicular health and ovarian cell proliferation, increased the number of active mitochondria and the intracellular level of the antioxidant glutathione, reduced ovarian cell ROS level and markers of apoptosis (PTEN/FOXO3a) pathway and mitigated the toxic effect of cisplatin on ovarian functions [110].

The other elderberry constituents, namely anthocyanins [105] including cyanidin [106] and nightshade anthocyanin [107], activated antioxidant enzymes and reduced the contents of ROS in embryonal cells. These changes were associated with improvement of embryo quality and viability $[105,106]$. These reports suggest that elderberry anthocyanins can boost embryo viability via the elimination of ROS-induced oxidative stress. In cultured cancer cells, another elderberry anthocyanin, delphinidin, was able to decrease the intracellular level of ATP, changed the intracellular amount of ROS and antioxidant glutathione and decreased the mitochondrial membrane potential and mitochondrial mass indicating oxidative stress-induced apoptosis [111]. In addition, delphinidin can suppress proliferation and migration of ovarian cell carcinoma cells through blocking AKT and ERK1/2 MAPK signaling pathways [96]. On the other hand, anthocyanidins possess weak phytoestrogenic properties $[99,100]$. Due to these properties, they could promote proliferation of estrogen-dependent cancer cells [99].

A similar mechanism of action on ovarian cancer cells was reported for black elderberry agglutinin. Chowdhury et al. [33] demonstrated that the suppressive action of the black elderberry constituent on ovarian cancer cells is mediated by a cascade of events:

(1) Black elderberry agglutinin activates the signaling pathways of AKT and ERK1/2, which promotes de-phosphorylation of dynamin-related protein-1 (Drp-1).

(2) Upon its translocation to the mitochondrial fission loci, Drp-1 induces fragmentation of the mitochondrial membrane.

(3) Mitochondrial outer membrane permeabilization results in the generation of ROS and cytochrome-c release into the cytosol-the signs of mitochondrial apoptosis.

(4) These changes may result in cell cycle arrest before the G2/M phase and programmed cell death.

Results of the study also demonstrated that black elderberry and its constituent rutin could promote healthy ovarian cell functions through the upregulation of gonadotropins, gonadotropin receptors, steroid hormones, antioxidants, reduction in oxidative stress and apoptosis, which in turn improves ovarian cell viability and fecundity. In contrast, in the case of ovarian cancer cells, elderberry and its constituents, rutin, anthocyanins and agglutinin, can suppress cell viability and functions via the downregulation of the similar mechanisms-AKT- and ERK1/2-dependent intracellular signaling pathways-promoters of cell proliferation and by induction of ROS-induced cytoplasmic/mitochondrial apoptosis. 
Understanding the causes of opposite action of elderberry and its molecules on healthy and cancer ovarian cells via similar intracellular mechanisms require further studies. Such studies could be helpful for possible application of elderberry for stimulation of healthy ovary and reproductive processes and suppression of ovarian cancer (see below). Available evidence concerning the possible regulators of female reproductive processes affected by black elderberry and its constituents are summarized in Figure 1.

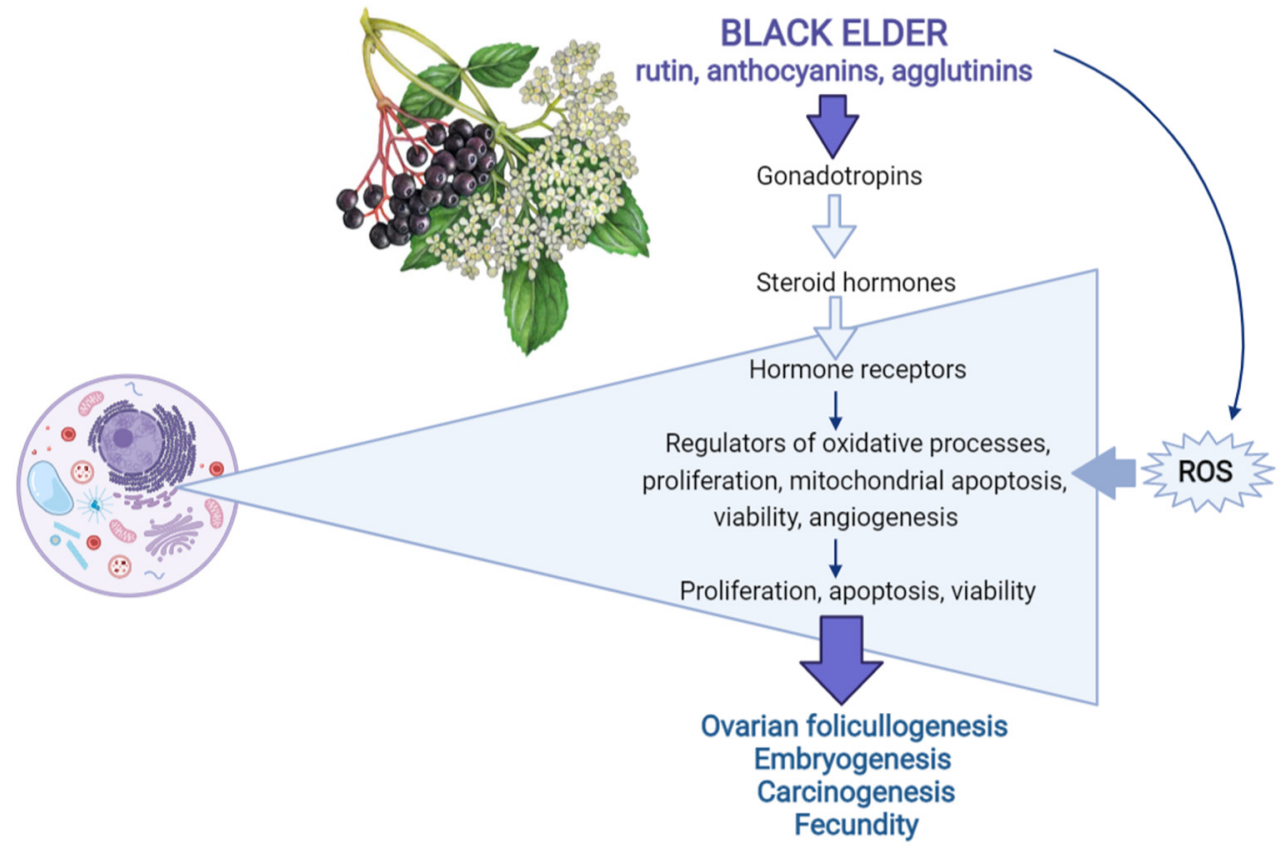

Figure 1. Regulators of female reproductive processes-targets of black elderberry (Sambucus nigra L.) and its constituents, rutin, anthocyanins and agglutinins (simplified). Explanations are provided in the text.

\section{Application in Reproductive Biology and Medicine}

The reported effects of black elderberry and its constituents on female reproductive processes summarized here indicate that these plant preparations could be stimulators of healthy ovarian cells and embryogenesis. It is not to be excluded that these preparations can support ovarian folliculogenesis, oogenesis, fecundity, embryogenesis and gravidity, to relieve the age-related reproductive insufficiency and menopause-related problems. As promoters of release and reception of gonadotropins and steroid hormones, as well as phytoestrogens, they could be useful in veterinary and human medicine for the treatment of disorders induced by a deficit of these hormones-age-related reproductive insufficiency, menopause-related problems, osteoporosis and polycystic ovarian syndrome. The ability of elderberry and its molecules to promote reproductive processes and fecundity could be useful in the induction of ovulation and superovulation in biotechnology in animal production and assisted reproduction. On the other hand, the ability of black elderberry substances to downregulate cell proliferation and viability of ovarian and trophoblast tumor cells indicates the potential ability of these substances for prevention, mitigation and treatment of ovarian and embryonal cancers.

Efficiency of elderberry's polyphenols could be increased by search of its safe and effective dosage, and the improvement of its stability, bioavailability and delivery by using nano-emulsion and nanoliposome systems, which can enhance the biological and therapeutic activity of these plant molecules [74,112].

Analysis of the available literature performed here shows that black elderberry contains several biologically active substances with different, sometimes opposite, actions. Some elderberry constituents could be toxic (see Section 2). Some other elderberry constituents have different chemical structures, but similar mechanisms of action 
(see Sections 4, 6 and 7). On the other hand, the substantial differences in character, targets (see Section 5) and mechanisms of action (see Sections 6 and 7) of various elderberry substances have been demonstrated. These facts indicate that the application of pure elderberry constituents with defined contents, amounts and effects could be more specific, controllable and efficient than the use of the whole crude plant extract. The published reports indicate that among the identified black elderberry constituents, rutin, anthocyanins (especially cyanidin-3-O-glucoside) and agglutinins could be molecules that are the most active and promising as both stimulators of reproductive functions and inhibitors of ovarian cancer. Both rutin and anthocyanins can promote gonadotropin release and reception, as well as promote ovarian cell functions. It is possible that these substances could be potentially useful as additives to gonadotropins for induction of ovarian folliculogenesis and the induction of ovulation and superovulation in animal biotechnology, assisted reproduction and medicine. On the other hand, only anthocyanins, but not rutin or agglutinins, were able to support embryogenesis. It is possible that anthocyanins could be applicable as additives to the culture medium for improvement of embryo development in in vitro embryo production. All the three mentioned elderberry constituents were shown to possess anticancer activity, and therefore all three preparations possess the potential to be useful in the management of ovarian cancer. Nevertheless, the number of reported studies is too modest to make a definite conclusion concerning elderberry constituent most suitable for particular biomedical applications.

\section{Conclusions and Possible Direction of Future Studies}

The reproductive effects of black elderberry extract and its constituents have been investigated insufficiently. Nevertheless, the published reports demonstrate the stimulatory influence of black elderberry extract and its constituents-rutin, anthocyanins and agglutinin - on steroid hormones and their receptors in ovarian and embryonal cells. The stimulatory influence of anthocyanins on embryogenesis has also been reported. On the other hand, rutin, anthocyanins and agglutinins can suppress ovarian and embryonal cancer cell functions. The effects of black elderberry and its molecules could be mediated by intracellular signaling pathways regulating cell proliferation, oxidative processes, cytoplas$\mathrm{mic} /$ mitochondrial apoptosis and viability, as well as by estrogen and estrogen receptors and angiogenesis. The available evidence indicates the potential usefulness of black elderberry extract and its constituents rutin and anthocyanins as biostimulators of female reproductive processes, as well as the potential applicability of whole elderberry extract, with rutin, anthocyanins and agglutinins, for the treatment of ovarian cancer and other reproductive disorders in animal biotechnology, animal production, assisted reproduction and veterinary and human medicine.

Nevertheless, the current state-of-art research invokes more queries concerning black elderberry action on female reproduction than answers. All biologically active constituents of black elderberry remain to be identified, and their biological activity remains to be investigated. The action of black elderberry extract has not been studied in in vivo experiments, whilst the reproductive effects of elderberry constituents were studied mainly in in vitro experiments and in a few animal studies. Adequate clinical studies have not been reported yet. Moreover, characteristics and mechanisms of action and biological activities of several elderberry constituents have not been compared in the same experiments yet. The conclusions concerning mechanisms of action of elderberry and its molecules are made mainly based on observations of changes in some signaling molecules after treatment, but the physiological role and functional interrelationships between particular signaling molecules remain rather hypothetical. Therefore, although the influence of black elderberry and its constituents on female reproductive processes has been demonstrated, its actions and potential applications require further studies. 
Author Contributions: Conceptualization, A.K. and A.V.S.; methodology, A.K.; software, A.K.; validation, A.K., S.B. and A.V.S.; formal analysis, A.V.S.; investigation, A.K., S.B., L.K. and A.V.S.; resources, L.K.; writing—original draft preparation, A.K. and S.B.; writing-review and editing, A.K. and A.V.S.; visualization, S.B.; supervision, A.K.; project administration, A.K.; funding acquisition, A.K. All authors have read and agreed to the published version of the manuscript.

Funding: This research was funded by the Ministry of Education, Science, Research and Sport of the Slovak Republic projects APVV-18-0312, DS-FR-19-0049, VEGA 1/0266/20, KEGA 033SPU4/2021, the Operational Programme Integrated Infrastructure within the project: Demand-driven research for the sustainable and innovative food, Drive4SIFood 313011V336, co-financed by the European Regional Development Fund, and ERASMUS+ Programme of the European Union KA2 2020-1-SK01-KA203-078363.

Institutional Review Board Statement: Not applicable.

Informed Consent Statement: Not applicable.

Data Availability Statement: No new data were created or analyzed in this study. Data sharing is not applicable to this article.

Acknowledgments: The authors thank Shubhadeep Roychoudhury for language editing and proofreading and the excellent scientific team "Center of Animal Reproduction (CeRA)" for their support.

Conflicts of Interest: The authors declare no conflict of interest.

\section{References}

1. Mee, J.F. Reproductive issues arising from different management systems in the dairy industry. Reprod. Domest. Anim. 2012, 47, 42-50. [CrossRef] [PubMed]

2. Canipari, R.; De Santis, L.; Cecconi, S. Female Fertility and Environmental Pollution. Int. J. Env. Res. Public Health 2020, $17,8802$. [CrossRef]

3. Roudebush, W.E.; Kivens, W.J.; Mattke, J.M. Biomarkers of Ovarian Reserve. Biomark. Insights 2008, 3, 259-268. [CrossRef]

4. Wojsiat, J.; Korczyński, J.; Borowiecka, M.; Żbikowska, H.M. The role of oxidative stress in female infertility and in vitro fertilization. Postepy Hig. Med. Dosw. 2017, 71, 359-366. [CrossRef]

5. Smits, R.M.; Mackenzie-Proctor, R.; Fleischer, K.; Showell, M.G. Antioxidants in fertility: Impact on male and female reproductive outcomes. Fertil. Steril. 2018, 110, 578-580. [CrossRef] [PubMed]

6. Akkol, E.K.; Dereli, F.T.G.; Sobarzo-Sánchez, E.; Khan, H. Roles of Medicinal Plants and Constituents in Gynecological Cancer Therapy: Current Literature and Future Directions. Curr. Top. Med. Chem. 2020, 20, 1772-1790. [CrossRef] [PubMed]

7. Sirard, M.A. 40 years of bovine IVF in the new genomic selection context. Reproduction 2018, 156, R1-R7. [CrossRef] [PubMed]

8. Sirotkin, A.; Záhoranska, Z.; Tarko, A.; Fabova, Z.; Alwasel, S.; Halim Harrath, A. Plant polyphenols can directly affect ovarian cell functions and modify toluene effects. J. Anim. Physiol. Anim. Nutr. 2021, 105, 80-89. [CrossRef]

9. Domínguez, R.; Zhang, L.; Rocchetti, G.; Lucini, L.; Pateiro, M.; Munekata, P.E.S.; Lorenzo José, M. Elderberry (Sambucus nigra L.) as potential source of antioxidants. Characterization, optimization of extraction parameters and bioactive properties. Food Chem. 2020, 330, 127266. [CrossRef]

10. Lorenzo, J.M.M.; Pateiro, M.; Domínguez, R.; Barba, F.J.; Putnik, P.; Kovačević, D.B.; Franco, D. Berries extracts as natural antioxidants in meat products: A review. Food Res. Int. 2018, 106, 1095-1104. [CrossRef]

11. Munekata, P.E.S.; Domínguez, R.; Campagnol, P.C.B.; Franco, D.; Trindade, M.A.; Lorenzo, J.M. Effect of natural antioxidants on physicochemical properties and lipid stability of pork liver pâté manufactured with healthy oils during refrigerated storage. $J$. Food Sci. Technol. 2017, 54, 4324-4334. [CrossRef] [PubMed]

12. Młynarczyk, K.; Walkowiak-Tomczak, D.; Łysiak, G.P. Bioactive properties of Sambucus nigra L. as a functional ingredient for food and pharmaceutical industry. J. Funct. Foods 2018, 40, 377-390. [CrossRef]

13. Milena, V.; Tatjana, M.; Gökhan, Z.; Ivana, B.; Aleksandra, C.; Mohammad, M.F.; Marija, R. Advantages of contemporary extraction techniques for the extraction of bioactive constituents from black elderberry (Sambucus nigra L.) flowers. Ind. Crops Prod. 2019, 136, 93-101. [CrossRef]

14. Integrated Taxonomic Information System. Available online: https://www.itis.gov/servlet/SingleRpt/SingleRpt?search_topic= TSN\&search_value=35315\#null (accessed on 6 October 2021).

15. Lim, T.K. Edible Medicinal and Non Medicinal Plants, 1st ed.; Springer: Dodrecht, The Netherlands, 2015; p. 1036. ISBN 978-94-0179510-4.

16. Finn, C.E.; Thomas, A.L.; Byers, P.L.; Serçe, S. Evaluation of American (Sambucus canadensis) and European (S. nigra) elderberry genotypes grown in diverse environments and implications for cultivar development. Hort. Sci. 2008, 43, 1385-1391. [CrossRef]

17. Senica, M.; Stampar, F.; Veberic, R.; Mikulic-Petkovsek, M. Processed elderberry (Sambucus nigra L.) products: A beneficial or harmful food alternative? LWT Food Sci. Technol. 2016, 72, 182-188. [CrossRef] 
18. Oniszczuk, A.; Olech, M.; Oniszczuk, T.; Wojtunik-Kulesza, K.; Wójtowicz, A. Extraction methods, LC-ESI-MS/MS analysis of phenolic compounds and antiradical properties of functional food enriched with elderberry flowers or fruits. Arab. J. Chem. 2016, 12, 4719-4730. [CrossRef]

19. Marisa Ribeiro, A.; Estevinho, B.N.; Rocha, F. Microencapsulation of polyphenols-The specific case of the microencapsulation of Sambucus nigra L. extracts-A review. Trends Food Sci. Technol. 2020, 105, 454-467. [CrossRef]

20. Ağalar, H.G. Elderberry (Sambucus nigra L.). In Nonvitamin and Nonmineral Nutritional Supplements, 1st ed.; Seyed, N., Nabavi, A.S., Eds.; Academic Press: Cambridge, MA, USA, 2019; Volume 1, pp. 211-215.

21. $\mathrm{Wu}, \mathrm{X}$.; Gu, L.; Prior, R.L.; McKay, S. Characterization of anthocyanins and proanthocyanidins in some cultivars of Ribes, Aronia, and Sambucus and their antioxidant capacity. J. Agric. Food Chem. 2004, 52, 7846-7856. [CrossRef] [PubMed]

22. Vlachojannis, C.; Zimmermann, B.F.; Chrubasik-Hausmann, S. Quantification of anthocyanins in elderberry and chokeberry dietary supplements. Phytother. Res. 2015, 29, 561-565. [CrossRef] [PubMed]

23. Drugs and Lactation Database (LactMed) Bethesda (MD): National Library of Medicine (US). Elderberry; 2006. Available online: https:/ / www.ncbi.nlm.nih.gov/books/NBK501835/ (accessed on 6 October 2021).

24. Krauze-Baranowska, M.; Malinowska, I.; Głód, D.; Majdan, M.; Wilczańska, A. UTLC of flavonols in Sambucus nigra flowers. J. Planar. Chromat. 2009, 22, 385-387. [CrossRef]

25. Chen, H.; Miao, Q.; Geng, M.; Liu, J.; Hu, Y.; Tian, L.; Pan, J.; Yang, Y. Anti-tumor effect of rutin on human neuroblastoma cell lines through inducing G2/M cell cycle arrest and promoting apoptosis. Sci. World J. 2013, 2013, 269165. [CrossRef] [PubMed]

26. Baldovska, S.; Roychoudhury, S.; Bandik, M.; Mihal, M.; Mnahoncakova, E.; Arvay, J.; Pavlik, A.; Slama, P.; Kolesarova, A. Ovarian steroid hormone secretion by human granulosa cells after supplementation of Sambucus nigra L. extract. Phys. Res. 2021, 70, 755-764. [CrossRef] [PubMed]

27. Stuppner, S.; Mayr, S.; Beganovic, A.; Beć, K.; Grabska, J.; Aufschnaiter, U.; Groeneveld, M.; Rainer, M.; Jakschitz, T.; Bonn, G.K.; et al. Near-Infrared Spectroscopy as a Rapid Screening Method for the Determination of Total Anthocyanin Content in Sambucus Fructus. Sensors 2020, 20, 4983. [CrossRef] [PubMed]

28. Vlachojannis, J.E.; Cameron, M.; Chrubasik, S. A systematic review on the sambuci fructus effect and efficacy profiles. Phytother. Res. 2010, 24, 1-8. [CrossRef]

29. Gleńsk, M.; Gliński, J.A.; Włodarczyk, M.; Stefanowicz, P. Determination of ursolic and oleanolic acid in Sambuci fructus. Chem. Biodivers. 2014, 11, 1939-1944. [CrossRef]

30. Krüger, S.; Mirgos, M.; Morlock, G.E. Effect-directed analysis of fresh and dried elderberry (Sambucus nigra L.) via hyphenated planar chromatography. J. Chromatogr. A 2015, 1426, 209-219. [CrossRef] [PubMed]

31. Salvador, A.C.; Rocha, S.M.; Silvestre, A.J.D. Lipophilic phytochemicals from elderberries (Sambucus nigra L.): Influence of ripening, cultivar and season. Ind. Crop. Prod. 2015, 71, 15-23. [CrossRef]

32. Tejero, J.; Jiménez, P.; Quinto, E.J.; Cordoba-Diaz, D.; Garrosa, M.; Cordoba-Diaz, M.; Gayoso, M.J.; Girbes, T. Elderberries: A source of ribosome-inactivating proteins with lectin activity. Molecules 2015, 20, 2364-2387. [CrossRef]

33. Chowdhury, S.R.; Ray, U.; Chatterjee, B.P.; Roy, S.S. Targeted apoptosis in ovarian cancer cells through mitochondrial dysfunction in response to Sambucus nigra agglutinin. Cell Death Dis. 2017, 8, e2762. [CrossRef]

34. Diviš, P.; Pořízka, J.; Vespalcová, M.; Matějíček, A.; Kaplan, J. Elemental composition of fruits from different black elder (Sambucus nigra L.) cultivars grown in the Czech Republic. J. Elem. 2015, 20, 549-557. [CrossRef]

35. Ho, G.T.; Zou, Y.F.; Wangensteen, H.; Barsett, H. RG-I regions from elderflower pectins substituted on GalA are strong immunomodulators. Int. J. Biol. Macromol. 2016, 92, 731-738. [CrossRef]

36. Ho, G.T.; Kase, E.T.; Wangensteen, H.; Barsett, H. Effect of Phenolic Compounds from Elderflowers on Glucose- and Fatty Acid Uptake in Human Myotubes and HepG2-Cells. Molecules 2017, 22, 90. [CrossRef] [PubMed]

37. Jørgensen, U.; Hansen, M.; Christensen, L.P.; Jensen, K.; Kaack, K. Olfactory and quantitative analysis of aroma compounds in elder flower (Sambucus nigra L.) drink processed from five cultivars. J. Agric. Food Chem. 2000, 48, 2376-2383. [CrossRef] [PubMed]

38. Buhrmester, R.A.; Ebinger1a, J.E.; Seigler, D.S. Sambunigrin and cyanogenic variability in populations of Sambucus canadensis L. (Caprifoliaceae). Biochem. Syst. Ecol. 2000, 28, 689-695. [CrossRef]

39. Ulbricht, C.; Basch, E.; Cheung, L.; Goldberg, H.; Hammerness, P.; Isaac, R.; Khalsa, K.P.S.; Romm, A.; Rychlik, I.; Varghese, M.; et al. An evidence-based systematic review of elderberry and elderflower (Sambucus nigra) by the Natural Standard Research Collaboration. J. Diet. Suppl. 2014, 11, 80-120. [CrossRef] [PubMed]

40. Torabian, G.; Bahramian, B.; Zambon, A.; Spilimbergo, S.; Adil, Q.; Schindeler, A.; Valtchev, P.; Dehghani, F. A hybrid process for increasing the shelf life of elderberry juice. J. Supercrit. Fluids 2018, 140, 406-414. [CrossRef]

41. Porter, R.S.; Bode, R.F. A Review of the Antiviral Properties of Black Elder (Sambucus nigra L.) Products. Phytother. Res. 2017, 31, 533-554. [CrossRef]

42. Frøkiær, H.; Henningsen, L.; Metzdorff, S.B.; Weiss, G.; Roller, M.; Flanagan, J.; Fromentin, E.; Ibarra, A. Astragalus root and elderberry fruit extracts enhance the IFN- $\beta$ stimulatory effects of Lactobacillus acidophilus in murine-derived dendritic cells. PLOS ONE 2012, 7, e47878. [CrossRef]

43. Waknine-Grinberg, J.H.; El-On, J.; Barak, V.; Barenholz, Y.; Golenser, J. The immunomodulatory effect of Sambucol on leishmanial and malarial infections. Planta Med. 2009, 75, 581-586. [CrossRef] [PubMed] 
44. Ho, G.T.; Wangensteen, H.; Barsett, H. Elderberry and Elderflower Extracts, Phenolic Compounds, and Metabolites and Their Effect on Complement, RAW 264.7 Macrophages and Dendritic Cells. Int. J. Mol. Sci. 2017, 18, 584. [CrossRef]

45. Burns, J.J.; Zhao, L.; Taylor, E.W.; Spelman, K. The influence of traditional herbal formulas on cytokine activity. Toxicology 2010, 278, 140-159. [CrossRef] [PubMed]

46. Olejnik, A.; Kowalska, K.; Olkowicz, M.; Rychlik, J.; Juzwa, W.; Myszka, K.; Dembczyński, R.; Białas, W. Anti-inflammatory effects of gastrointestinal digested Sambucus nigra L. fruit extract analyzed in co-cultured intestinal epithelial cells and lipopolysaccharidestimulated macrophages. J. Funct. Foods 2015, 19, 649-660. [CrossRef]

47. Dawidowicz, A.L.; Wianowska, D.; Baraniak, B. The antioxidant properties of alcoholic extracts from Sambucus nigra L. (antioxidant properties of extracts). LWT Food Sci. Technol. 2006, 39, 308-315. [CrossRef]

48. Denev, P.; Ciz, M.; Ambrozova, G.; Lojek, A.; Yanakieva, I.; Kratchanova, M. Solid-phase extraction of berries' anthocyanins and evaluation of their antioxidative properties. Food Chem. 2010, 123, 1055-1061. [CrossRef]

49. Sun-Waterhouse, D.; Jin, D.; Waterhouse, G.I.N. Effect of adding elderberry juice concentrate on the quality attributes, polyphenol contents and antioxidant activity of three fibre-enriched pastas. Food Res. Int. 2013, 54, 781-789. [CrossRef]

50. Topolska, D.; Valachova, K.; Rapta, P.; Silhar, S.; Panghyova, E.; Horvath, A.; Soltes, L. Antioxidative properties of Sambucus nigra extracts. Chem. Pap. 2015, 69, 1202-1210. [CrossRef]

51. Arjoon, A.V.; Saylor, C.V.; May, M. In Vitro efficacy of antimicrobial extracts against the atypical ruminant pathogen Mycoplasma mycoides subsp. capri. BMC Complement. Altern. Med. 2012, 12, 169. [CrossRef]

52. Jonušaite, K.; Venskutonis, P.R.; Martínez-Hernández, G.B.; Nieto, G.; López-Gómez, A.; Marín-Iniesta, F. Antioxidant and Antimicrobial Effect of Plant Essential Oils and Sambucus nigra Extract in Salmon Burgers. Foods 2021, 10, 776. [CrossRef]

53. Roschek, B.; Fink, R.C.; McMichael, M.D.; Li, D.; Alberte, R.S. Elderberry flavonoids bind to and prevent H1N1 infection in vitro. Phytochemistry 2009, 70, 1255-1261. [CrossRef]

54. Kinoshita, E.; Hayashi, K.; Katayama, H.; Hayashi, T.; Obata, A. Anti-influenza virus effects of elderberry juice and its fractions. Biosci. Biotechnol. Biochem. 2012, 76, 1633-1638. [CrossRef]

55. Zafra-Stone, S.; Yasmin, T.; Bagchi, M.; Chatterjee, A.; Vinson, J.A.; Bagchi, D. Berry anthocyanins as novel antioxidants in human health and disease prevention. Mol. Nutr. Food Res. 2007, 51, 675-683. [CrossRef]

56. Araújo, K.C.F.; de MBCosta, E.M.; Pazini, F.; Valadares, M.C.; de Oliveira, V. Bioconversion of quercetin and rutin and the cytotoxicity activities of the transformed products. Food Chem. Toxicol. 2013, 51, 93-96. [CrossRef]

57. Schröder, L.; Richter, D.U.; Piechulla, B.; Chrobak, M.; Kuhn, C.; Schulze, S.; Abarzua, S.; Jeschke, U.; Weissenbacher, T. Effects of Phytoestrogen Extracts Isolated from Elder Flower on Hormone Production and Receptor Expression of Trophoblast Tumor Cells JEG-3 and BeWo, as well as MCF7 Breast Cancer Cells. Nutrients 2016, 8, 616. [CrossRef] [PubMed]

58. Pereira, D.I.; Amparo, T.R.; Almeida, T.C.; Costa, F.S.F.; Brandão, G.C.; Santos, O.D.H.D.; da Silva, G.N.; Bianco de Souza, G.H Cytotoxic activity of butanolic extract from Sambucus nigra L. flowers in natura and vehiculated in micelles in bladder cancer cells and fibroblasts. Nat. Prod. Res. 2020, 1-9. [CrossRef] [PubMed]

59. Ma, X.; Ning, S. Cyanidin-3-glucoside attenuates the angiogenesis of breast cancer via inhibiting STAT3/VEGF pathway. Phytother. Res. 2019, 33, 81-89. [CrossRef] [PubMed]

60. Abdel-Naim, A.B.; Alghamdi, A.A.; Algandaby, M.M.; Al-Abbasi, F.A.; Al-Abd, A.M.; Eid, B.G.; Abdallah, H.M.; El-Halawany, A.M. Rutin Isolated from Chrozophora tinctoria Enhances Bone Cell Proliferation and Ossification Markers. Oxid. Med. Cell Longev. 2018, 2018, 5106469. [CrossRef] [PubMed]

61. Ataee, R.; Falahati, A.; Ebrahimzadeh, M.A.; Shokrzadeh, M. Anticonvulsant activities of Sambucus nigra. Eur. Rev. Med. Pharmacol. Sci. 2016, 20, 3123-3126. [PubMed]

62. Kashi, D.S.; Shabir, A.; Boit, M.D.; Bailey, S.J.; Higgins, M.D. The Efficacy of Administering Fruit-Derived Polyphenols to Improve Health Biomarkers, Exercise Performance and Related Physiological Responses. Nutrients 2019, 11, 2389. [CrossRef]

63. Mahmoudi, M.; Ebrahimzadeh, M.A.; Dooshan, A.; Arimi, A.; Ghasemi, N.; Fathiazad, F. Antidepressant activities of Sambucus ebulus and Sambucus nigra. Eur. Rev. Med. Pharmacol. Sci. 2014, 18, 3350-3353.

64. Blumenthal, M.; Goldberg, A.; Brinckmann, J. Herbal Medicine. Expanded Commission E Monographs; Integrative Medicine Communications: Newton, MA, USA, 2000; ISBN 0967077214.

65. Weiss, R.F.; Fintelmann, V. Herbal Medicine, 2nd ed.; Thieme: New York, NY, USA, 2000; p. 448. ISBN 0865779708.

66. Lin, P.; Hwang, E.; Ngo, H.T.T.; Seo, S.A.; Yi, T.H. Sambucus nigra L. ameliorates UVB-induced photoaging and inflammatory response in human skin keratinocytes. Cytotechnology 2019, 71, 1003-1017. [CrossRef]

67. Chen, C.; Zuckerman, D.M.; Brantley, S.; Sharp, M.; Childress, K.; Hoiczyk, E.; Pendleton, F.A.R. Sambucus nigra extracts inhibit infectious bronchitis virus at an early point during replication. BMC Vet. Res. 2014, 10, 24. [CrossRef]

68. Torabian, G.; Valtchev, P.; Adil, Q.; Dehghani, F. Anti-influenza activity of elderberry (Sambucus nigra). J. Funct. Foods 2019, 54, 353-360. [CrossRef]

69. Harnett, J.; Oakes, K.; Carè, J.; Leach, M.; Brown, D.; Cramer, H.; Pinder, T.A.; Steel, A.; Anheyer, D. The effects of Sambucus nigra berry on acute respiratory viral infections: A rapid review of clinical studies. Adv. Integr. Med. 2020, 7, 240-246. [CrossRef] [PubMed]

70. Badescu, L.; Badulescu, O.; Badescu, M.; Ciocoiu, M. Mechanism by Sambucus nigra Extract Improves Bone Mineral Density in Experimental Diabetes. Evid. Based Complement. Alternat. Med. 2012, 2012, 848269. [CrossRef] 
71. Bhattacharya, S.; Christensen, K.B.; Olsen, L.C.; Christensen, L.P.; Grevsen, K.; Færgeman, N.J.; Kristiansen, K.; Young, J.F.; Oksbjerg, N. Bioactive components from flowers of Sambucus nigra L. increase glucose uptake in primary porcine myotube cultures and reduce fat accumulation in Caenorhabditis elegans. J. Agric. Food Chem. 2013, 61, 11033-11040. [CrossRef] [PubMed]

72. Christensen, K.B.; Petersen, R.K.; Kristiansen, K.; Christensen, L.P. Identification of bioactive compounds from flowers of black elder (Sambucus nigra L.) that activate the human peroxisome proliferator-activated receptor (PPAR) gamma. Phytother. Res. 2010, 24, S129-S132. [CrossRef] [PubMed]

73. Gray, A.M.; Abdel-Wahab, Y.H.; Flatt, P.R. The traditional plant treatment, Sambucus nigra (elder), exhibits insulin-like and insulin-releasing actions in vitro. J. Nutr. 2000, 130, 15-20. [CrossRef] [PubMed]

74. Jiang, H.; Zhang, W.; Li, X.; Xu, Y.; Cao, J.; Jiang, W. The anti-obesogenic effects of dietary berry fruits: A review. Food Res. Int. 2021, 147, 110539. [CrossRef] [PubMed]

75. Farrell, N.J.; Norris, G.H.; Ryan, J.; Porter, C.M.; Jiang, C.; Blesso, C.N. Black elderberry extract attenuates inflammation and metabolic dysfunction in diet-induced obese mice. Br. J. Nutr. 2015, 114, 1123-1131. [CrossRef] [PubMed]

76. Duymuş, H.G.; Göger, F.; Başer, K.H.C. In vitro antioxidant properties and anthocyanin compositions of elderberry extracts. Food Chem. 2014, 155, 112-119. [CrossRef]

77. Moldovan, B.; David, L.; Achim, M.; Clichici, S.; Filip, G.A. A green approach to phytomediated synthesis of silver nanoparticles using Sambucus nigra L. fruits extract and their antioxidant activity. J. Mol. Liq. 2016, 221, 271-278. [CrossRef]

78. Silva, P.; Ferreira, S.; Nunes, F.M. Elderberry (Sambucus nigra L.) by-products a source of anthocyanins and antioxidant polyphenols. Ind. Crops Prod. 2017, 95, 227-234. [CrossRef]

79. Iacopini, P.; Baldi, M.; Storchi, P.; Sebastiani, L. Catechin, epicatechin, quercetin, rutin and resveratrol in red grape: Content, in vitro antioxidant activity and interactions. J. Food Compost. Anal. 2008, 21, 589-598. [CrossRef]

80. Bagchi, D.; Sen, C.K.; Bagchi, M.; Atalay, M. Anti-angiogenic, antioxidant, and anti-carcinogenic properties of a novel anthocyaninrich berry extract formula. Biochemistry 2004, 69, 75-80. [CrossRef] [PubMed]

81. Malagolini, N.; Catera, M.; Osorio, H.; Reis, C.A.; Chiricolo, M.; Dall’Olio, F. Apoptotic cells selectively uptake minor glycoforms of vitronectin from serum. Apoptosis 2013, 18, 373-384. [CrossRef]

82. Chiodelli, P.; Rezzola, S.; Urbinati, C.; Federici Signori, F.; Monti, E.; Ronca, R.; Presta, M.; Rusnati, M. Contribution of vascular endothelial growth factor receptor-2 sialylation to the process of angiogenesis. Oncogene 2017, 36, 6531-6541. [CrossRef]

83. Ho, G.T.T.; Ahmed, A.; Zou, Y.F.; Aslaksen, T.; Wangensteen, H.; Barsett, H. Structure-activity relationship of immunomodulating pectins from elderberries. Carbohydr. Polym. 2015, 125, 314-322. [CrossRef] [PubMed]

84. Barsett, H.; Aslaksen, T.H.; Gildhyal, P.; Michaelsen, T.E.; Paulsen, B.S. Comparison of carbohydrate structures and immunomodulating properties of extracts from berries and flowers of Sambucus nigra L. Eur. J. Med. Plants 2012, 2, 216-229. [CrossRef]

85. Sirotkin, A.V.; Harrath, A.H. Phytoestrogens and their effects. Eur. J. Pharmacol. 2014, 741, 230-236. [CrossRef]

86. Lin, Y.; Jiang, M.; Chen, W.; Zhao, T.; Wei, Y. Cancer and ER stress: Mutual crosstalk between autophagy, oxidative stress and inflammatory response. Biomed. Pharmacother. 2019, 118, 109249. [CrossRef]

87. Wang, Y.; Chen, F.; Ye, L.; Zirkin, B.; Chen, H. Steroidogenesis in Leydig cells: Effects of aging and environmental factors. Reproduction 2017, 154, R111-R122. [CrossRef]

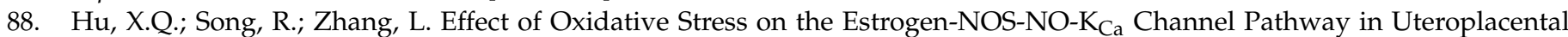
Dysfunction: Its Implication in Pregnancy Complications. Oxid. Med. Cell Longev. 2019, 2019, 9194269. [CrossRef] [PubMed]

89. Sirotkin, A.V.; Radosová, M.; Tarko, A.; Fabova, Z.; Martín-García, I.; Alonso, F. Abatement of the Stimulatory Effect of Copper Nanoparticles Supported on Titania on Ovarian Cell Functions by Some Plants and Phytochemicals. Nanomaterials 2020, 10, 1859. [CrossRef] [PubMed]

90. Hu, T.; Yuan, X.; Ye, R.; Zhou, H.; Lin, J.; Zhang, C.; Zhang, H.; Wei, G.; Dong, M.; Huang, Y.; et al. Brown adipose tissue activation by rutin ameliorates polycystic ovary syndrome in rat. J. Nutr. Biochem. 2017, 47, 21-28. [CrossRef] [PubMed]

91. Wang, X.; Wang, G.C.; Rong, J.; Wang, S.W.; Ng, T.B.; Zhang, Y.B.; Lee, K.F.; Zheng, L.; Wong, H.K.; Yung, K.K.L.; et al. Identification of Steroidogenic Components Derived from Gardenia jasminoides Ellis Potentially Useful for Treating Postmenopausal Syndrome. Front. Pharmacol. 2018, 9, 390. [CrossRef] [PubMed]

92. Luo, H.; Jiang, B.H.; King, S.M.; Chen, Y.C. Inhibition of cell growth and VEGF expression in ovarian cancer cells by flavonoids. Nutr. Cancer 2008, 60, 800-809. [CrossRef] [PubMed]

93. De Araújo, M.E.; Moreira Franco, Y.E.; Alberto, T.G.; Sobreiro, M.A.; Conrado, M.A.; Priolli, D.G.; Frankland Sawaya, A.C.; Ruiz, A.L.; de Carvalho, J.E.; de Oliveira Carvalho, P. Enzymatic de-glycosylation of rutin improves its antioxidant and antiproliferative activities. Food Chem. 2013, 141, 266-273. [CrossRef]

94. Aqil, F.; Jeyabalan, J.; Agrawal, A.K.; Kyakulaga, A.H.; Munagala, R.; Parker, L.; Gupta, R.C. Exosomal delivery of berry anthocyanidins for the management of ovarian cancer. Food Funct. 2017, 8, 4100-4107. [CrossRef]

95. Diaconeasa, Z.; Leopold, L.; Rugină, D.; Ayvaz, H.; Socaciu, C. Antiproliferative and antioxidant properties of anthocyanin rich extracts from blueberry and blackcurrant juice. Int. J. Mol. Sci. 2015, 16, 2352-2365. [CrossRef]

96. Lim, W.; Jeong, W.; Song, G. Delphinidin suppresses proliferation and migration of human ovarian clear cell carcinoma cells through blocking AKT and ERK1/2 MAPK signaling pathways. Mol. Cell Endocrinol. 2016, 422, 172-181. [CrossRef]

97. Sirotkin, A.; Záhoranska, Z.; Tarko, A.; Popovska-Percinic, F.; Alwasel, S.; Harrath, A.H. Plant isoflavones can prevent adverse effects of benzene on porcine ovarian activity: An in vitro study. Environ. Sci. Pollut. Res. Int. 2020, 27, 29589-29598. [CrossRef] [PubMed] 
98. Sirotkin, A.V. Regulators of Ovarian Functions; Nova Publishers: New York, NY, USA, 2014; p. 194. ISBN 978-1-62948-574-4.

99. Schmitt, E.; Stopper, H. Estrogenic activity of naturally occurring anthocyanidins. Nutr. Cancer 2001, 41, 145-149. [CrossRef] [PubMed]

100. Nanashima, N.; Horie, K.; Maeda, H. Phytoestrogenic Activity of Blackcurrant Anthocyanins Is Partially Mediated through Estrogen Receptor Beta. Molecules 2017, 23, 74. [CrossRef] [PubMed]

101. Wu, Y.; Hankinson, S.E.; Smith-Warner, S.A.; Wang, M.; Eliassen, A.H. Flavonoid Intake and Plasma Sex Steroid Hormones, Prolactin, and Sex Hormone-Binding Globulin in Premenopausal Women. Nutrients 2019, 11, 2669. [CrossRef] [PubMed]

102. Li, X.; Guo, J.; Jiang, X.; Sun, J.; Tian, L.; Jiao, R.; Tang, Y.; Bai, W. Cyanidin-3-O-glucoside protects against cadmium-induced dysfunction of sex hormone secretion via the regulation of hypothalamus-pituitary-gonadal axis in male pubertal mice. Food Chem. Toxicol. 2019, 129, 13-21. [CrossRef]

103. Amado, N.G.; Fonseca, B.F.; Cerqueira, D.M.; Reis, A.H.; Simas, A.B.; Kuster, R.M.; Mendes, F.A.; Abreu, J.G. Effects of natural compounds on Xenopus embryogenesis: A potential read out for functional drug discovery targeting Wnt/ $\beta$-catenin signaling. Curr. Top. Med. Chem. 2012, 12, 2103-2113. [CrossRef]

104. Matsuo, M.; Sasaki, N.; Saga, K.; Kaneko, T. Cytotoxicity of flavonoids toward cultured normal human cells. Biol. Pharm. Bull. 2005, 28, 253-259. [CrossRef]

105. You, J.; Kim, J.; Lim, J.; Lee, E. Anthocyanin stimulates in vitro development of cloned pig embryos by increasing the intracellular glutathione level and inhibiting reactive oxygen species. Theriogenology 2010, 74, 777-785. [CrossRef]

106. Hicks, E.; Mentler, M.; Arena, H.A.; Current, J.Z.; Whitaker, B.D. Cyanidin improves oocyte maturation and the in vitro production of pig embryos. In Vitro Cell Dev. Biol. Anim. 2020, 56, 577-584. [CrossRef]

107. Xie, N.; Geng, N.; Zhou, D.; Xu, Y.; Liu, K.; Liu, Y.; Liu, J. Protective effects of anthocyanin against apoptosis and oxidative stress induced by arsanilic acid in DF-1 cells. Mol. Biol. Rep. 2019, 46, 301-308. [CrossRef]

108. Massimiani, M.; Lacconi, V.; La Civita, F.; Ticconi, C.; Rago, R.; Campagnolo, L. Molecular Signaling Regulating EndometriumBlastocyst Crosstalk. Int. J. Mol. Sci. 2019, 21, 23. [CrossRef] [PubMed]

109. Valko-Rokytovská, M.; Očenáš, P.; Salayová, A.; Kostecká, Z. Breast Cancer: Targeting of Steroid Hormones in Cancerogenesis and Diagnostics. Int. J. Mol. Sci. 2021, 22, 5878. [CrossRef] [PubMed]

110. Lins, T.L.B.G.; Gouveia, B.B.; Barberino, R.S.; Silva, R.L.S.; Monte, A.P.O.; Pinto, J.G.C.; Campinho, D.S.P.; Palheta, R.C.; Matos, M.H.T. Rutin prevents cisplatin-induced ovarian damage via antioxidant activity and regulation of PTEN and FOXO3a phosphorylation in mouse model. Reprod. Toxicol. 2020, 98, 209-217. [CrossRef] [PubMed]

111. Pieńkowska, N.; Bartosz, G.; Furdak, P.; Sadowska-Bartosz, I. Delphinidin Increases the Sensitivity of Ovarian Cancer Cell Lines to 3-Bromopyruvate. Int. J. Mol. Sci. 2021, 22, 709. [CrossRef] [PubMed]

112. Chen, B.H.; Stephen Inbaraj, B. Nanoemulsion and Nanoliposome Based Strategies for Improving Anthocyanin Stability and Bioavailability. Nutrients 2019, 11, 1052. [CrossRef] 